THE BLACK POWER MOVEMENT AND AMERICAN SOCIAL WORK 



\section{The Black Power Movement and American Social Work}

Joyce M. Bell 


\section{COLUMBIA UNIVERSITY PRESS}

Publishers Since 1893

New York Chichester, West Sussex

cup.columbia.edu

Copyright (C) 2014 Columbia University Press

All rights reserved

Library of Congress Cataloging-in-Publication Data

Bell, Joyce Marie.

The Black power movement and American social work / Joyce M. Bell. pages $\mathrm{cm}$

Includes bibliographical references and index.

ISBN 978-0-23I-I6260-9 (cloth : alk. paper) — ISBN 978-0-23I-5380I-5 (e-book)

I. African American social workers-History-2oth century. 2. Black power-United States. 3. Social workers-United States-History-2oth century. 4. Social service-United States-History-2oth century. I. Title.

$\mathrm{HV}_{40.8 . U 6 B_{45} 2014}$

361.3089'96073-dc23

Columbia University Press books are printed on permanent and durable acid-free paper. This book is printed on paper with recycled content.

Printed in the United States of America

c $109 \begin{array}{lllllllll} & 9 & 7 & 6 & 5 & 4 & 3 & 2 & 1\end{array}$

COVER DESIGN: Chang Jae Lee

References to websites (URLs) were accurate at the time of writing. Neither the author nor Columbia University Press is responsible for URLs that may have expired or changed since the manuscript was prepared. 
FOR MY MOTHER JEAN ANNAN, AND FOR MY GUYS TYEHIMBA BELL AND TYEHIMBA RALASI, WITH LOVE. 
